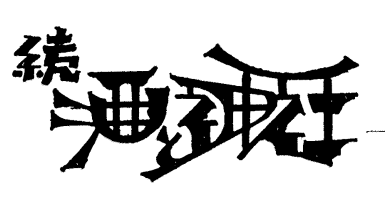

\title{
酒神と神社 (10)
}

\section{9 造酒司酒殿坐神}

『延喜式』(巻 40) の「造酒百」条に「祭神九座春秋 竝同」とみ穴，その内訳を次のように録している。

二座蓜弥豆男神・酒弥豆女神 徒五位上

四座 䇫神

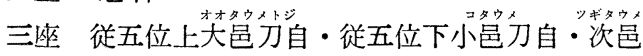
刀自

平安京大内裏の造酒司の酒殿には, これら 9 座の神々が 奉斎されていたことが知られる。しかし，これらの神々 が平安京以前, つまり平城京や大和の藤原京などの造酒 司にも斎荆されていたかどうかは不詳である。

本稿では, 宮中造酒司に祭祀しく脂酒>が醉されるよ らに祈念した「祭神九座」とは，どのような神であった か, これらの神々の出所ばかりか, その神徳についても 考察する。

\subsection{1 酒弥豆男神・酒弥豆女神}

造酒司の「二座 酒弥豆男神・酒弥豆女神」は, 従前 から，5世紀前期, 苩済から来朝した兽々保利兄妹に比 定されている。この説は, 江戸後期の国学者尾代弘賢の 『古今要覽稿』に,

造酒司にまします神六座のうち四座は大なり，二座 は小なり……(中略)……小二座は酒弥豆男・酒弥豆女 の神にして，大䳡葽天皇（德天皇）の御代に韓国よ り参来し兄曾々保利・弟曾々保利の事 (姓氏録)な れば小としるされしなるべし

とある記事から引き出すことができる。この所説は『新 撰姓氏録』の「右京皇別」の「酒部公齐」条に,

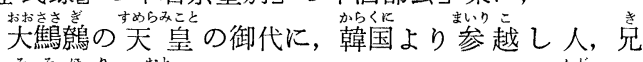
普々保利, 第曾々保利の二人あり, 天皇何の架か有 ると勅うに, 酒を造るの才有りと皆す。御酒を 造らしむ。是に於て厤に酒看都子という告を賜い, 崖展比㖕に酒看都女という号を賜う。架, 酒看都を

\section{加藤 百一}

\section{以て氏と為す}

とある記事を引用したことは明らかである。また『特撰 神名牌』(教部省編, 大正14年) に上れば, 造酒司の「酒殿, 神社 二座」酒弥豆男神・酒弥豆女神について,

今按姓氏録に, 酒部公, 大足彦忍代別皇(景行 天皇) 神櫛別命三世孫足彦大兄定之後也……(中略) ……女あるてて, 酒弥豆男神は酒部公麻虽, 酒弥豆 女神は山鹿比咩なること明けし

と見光，同姓氏録の記事をそのまま支持している。

これら両書は, いずれも『古事記』(応神記)に,

秦造の祖, 漢直の祖, 笈酒を䁔むことを知孔 る人, 名は㟀番, 亦の名は韻鿓䛨理等, 参渡り来つ と語られていることを全く意識しないで叙述したとは思 われない。ここで興味あることといえば, 曾々保利と須 々許理とは偶然にも類似的な名前であること, さらに彼 らが登場する応神・化徳両王朝 ( 5 世紀前期) の時代落差は, 20 年と距っていないことである。これらの点については いずれ別稿で考証する。

次に, 曾々保利兄妹が造酒司酒殿の成立当初から斉形 されていたかどらか，造酒司の成立と併せて考察する。

宮内省に隸属する造酒司の確立は, 律令政府の官僚組 織が一応整えられた 7 世紀であろらが, 酒人らの下部組 織の編成化は 6 世紀といわれているので, 造酒司の成立 をみ沉のはちょらどこのころであろら。しかし，実際的 にその荆芽はすでに 7 世紀後半に見られる。こうした官 人の組織化に大きな役割を果したのが，〈今来漢人〉と いわれた㷌化人であった。大陸からの技術導入は 4 世期 末期から 5 世紀, 壬德王朝 以降である ${ }^{1}$ が, 実際鉄工・ 鍛治工・武器工・織工・縫工など，高度の技術を身につ けた人々が集団的に来朝したのは 5 世紀後半であった。 曾々保利兄妹の渡来は, こうした渡来説話の一部として 理解することができよう。

ところで，もし曾々保利兄妹が造鸿司の成立当初から 
祭妧されていたとすれば,『姓氏録』の「酒部公」の条 ばかりか，その他注文献的確証が見出されてもよいは ずであるが，全くそのような記事は見当らない。とすれ ば, 曾々保利兄妹が造酒司酒殿の守護神として奉祀され た時期は, 造酒司の成立当初ではなかったと考光る潘か はない。では, その時期はとい党ば, 造酒司が成立した と思われる 5 世紀後半から, 『延喜式』が編さんされた 9 世期前期の間といら大なかな見通しはできても, これ を鲑付ける傍証史料が見出せない限り, これ以上のこと は何ともいえない。

ここで着目すべきことは，酒弥豆男神・酒弥豆女神は く酒称〉を守護する神を男女二神とみなし, 造酒所に祭 效したとする式内社研究会の調查報告) である。く酒 水〉は酒を醇すのに最も必要な浄水之注書しているもの の, これらの 2 神がどの神に比定されるのか, 同報告は 明記していない。今 $1 つ$ 注目すべきこととして同報告は,

新撰姓氏録によって酒部公の祖, 麻呂 - 山鹿比咩に 充てる説もあるが従いがたい

と, 『姓氏 録』以来の通説を真っ向から否定しているこ とである。しかし，その理由については触れていない。

これをで酒弥豆男神・酒弥豆女神の男女二神の出自に ついて, 考証を重叔てきたにもかかわらず, これら両神 が具体的にどの神に比定されるか不詳といらほかないで あろら。しかし, これら男女二神が, 式内社研究会の調 查報告の上らに<酒水>つまり酒造用水の守護神として 崇敬されたことは, 造酒司の酒人らが酒造りに当って, いかに醸造用水を神聖視し, 旨酒が造られるように仕达 水に限りない願望と新りを献げていたかが想像される。

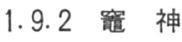

酒造りに当って, 次に神聖視されたのは箒であった。 造酒司の簡神について, まずその出自を『記・紀』神話 から,ささに民間信仰的見地から考察を加光る。

(1) 䇫神に関する神話的考察

䆚神といえば, 『古事記』(神代記) 飞,

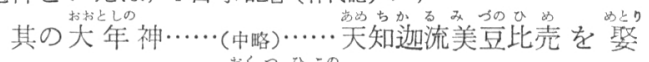
して生める子は, 奧㴖日子神, 次棌津比売命, 亦

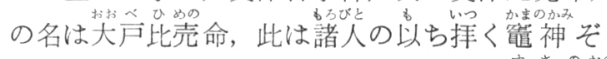

と語られているよらに, 大年神の娘, つまり䝴苃之男命 の棌娘垱る当津比売命のことである。彼女の別名, 大 戸比売の「大戸」は大䆰の意であるから, 彼女は明らか にカマドあるいはヘッッイをつかさどる神である。した がって『延喜式』(卷 40, 造酒司) の「四座 霆神」のら台 の1座は, まぎれもなく奥津比売命である。ところが, 他の 3 座がと゚の神々に当るのか, 『記・紀』神話から直 接的に見出すことはできない。

たまたま『古今要覧稿』に，
造酒司にまします神六座のうち四座大なり，二座は 小なり，大四座は大宮売神㲸して大年神の御子也 とある。とすれば「大四座」の神が大年神の御子である のは確しかであるが, 大宮売神のらちの一座が, そのま ま䆠神ともいわれた奥津比売神と同一神であったかどう

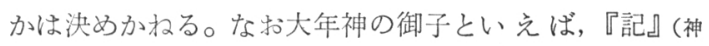
代記) の同条に,

大年神の子, 大国御魂神以下, 大土神以羡箭は咞せて 十六神

と語られているように, 伊怒比孪との間に 5 神, 香用比 売との間に 2 神, 天知迦流美豆比売との間に 9 神（実際 は10 神) の, 計 17 柱の神々が数兄らる。となると, ますます「大四座」に該当する神々が，一体どの神に該 当するか全く判断苦しむ。

ところが，『特撰神名皤』によると，「造酒司坐神六座」 の「大四座」には大亳津姫神・大宮津彦神・大楖膳津 神・大御膳姫神の 4 神を当てている。その理由は,

今按執政所抄宮咩垔祭文飞維天治二年 (1125) 歳次乙 己云々, 高御魂命 - 大宮津彦 - 大宮津姫 - 大御嘻津 命・大御嘻津姫五柱乃皇大御神之広前云々

であるといい, なお「篙御魂命を除き奉る事著けれぱ 今定め」たとしている。また造酒司に「大宮売神四座」, つまり「大四座」を奉斎していたことは, 『延喜式』(巻 1 , 神祀・D正 の「四時祭上」条に, 大宮売神四座祭坐二造造司一

とあるより明らかである。大宮売神については, 『古語 拾遺』は「大宮売神 シシテ御前二侍ラシ」め, 御酒を奉 って「宸祭习悦懌ナラシム也」と説明している。しかし， いずれにしても両書の考証は不適確のそしりをま妨がれ ないであろう。

次に大御膳津神の出自について, 同牌は『大倭本記』

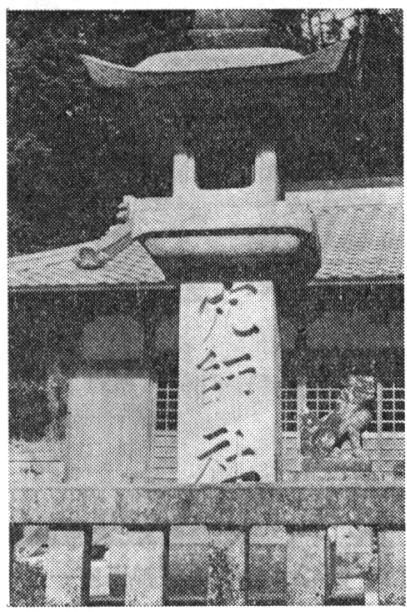

写真 1.41 穴師坐兵主神社(大兵主神社)の据殿 
の記事を引用して，

天皇ノ始メテ降リ来ルノ時, 共飞護斎鏡三面子鈴一 合 副エ云々。一鏡及ビ子鈴八天皇ノ御食津神朝, 御食夜, 御食, 夜ノ護り日ノ蓝り卜斎キ奉ル大神八,

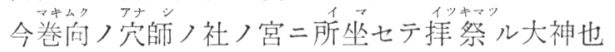
と述べている。したがって『延喜式』(卷 9 , 神名・上) の 「大和国者上郡」条, 卷尚坐若御魂神社飞斎祀され ているこの神が, 天皇の御食事ばかりか, 水稲作りにつ いても，また酒造りにも深い掛り合いをもっていたと思 われる。しかし，このことを裏書さする傍証資料が見出 せないのでいささか心細い。な散卷向坐御魂神社は、今 日奈良県桜井市穴師町飞鎮委る旧县社・㞣師坐兵主神 社 (大兵主神社) に, 大兵主神 - 兵主神と共に三座一社 殷として祭妧されている。

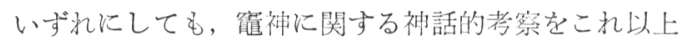
進めるのは, 文献的には無理の上らである。

（2）窝神に対する民間信仰的考察

䆮神については民間信仰で広く知られているが，ここ

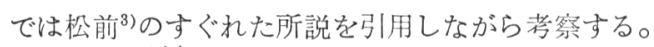

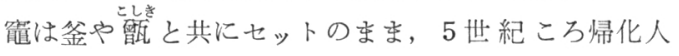
がもたらしたものといわれ, 畿内から次第に畿外へと拡 がっていった。『延喜式』にはよく「韓鼃」といら語が

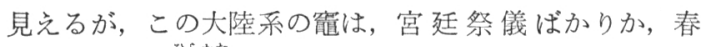
日・大原野・枚方・平野などの大社にも祭邧料とし供与 され, 神錨の調理や神酒造りなどに使われたので大そう 神聖視されていた。特に祭妧用には「庭篦」といって, 神社の内苑や別棟にしつらえた大筐が使われていた。た と光ば伊勢神宮の总火屋殿とか，また『止由気宮(外宮)儀

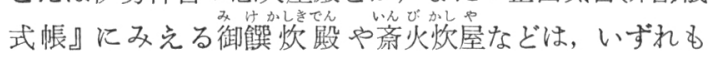

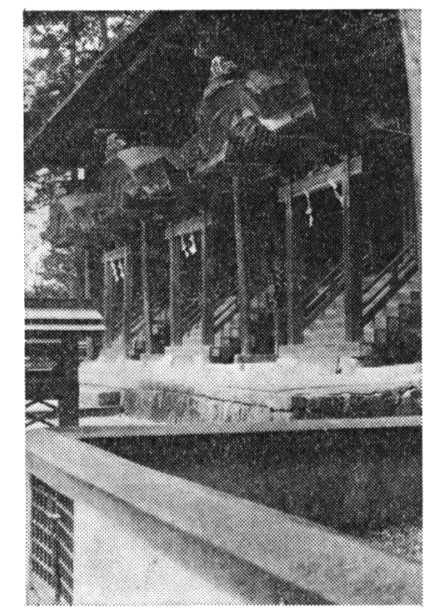

写真 1.42 同社は祭神三座一社殿 右端:『延喜式』(神名帳) に及光る「巻向坐若御魂神」(大御善津神) 中央：兵主神

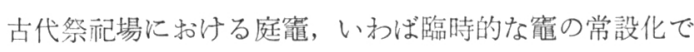
あったと思われる。

古代宮廷内における䇴神, たと兄ば天皇の食事を取り

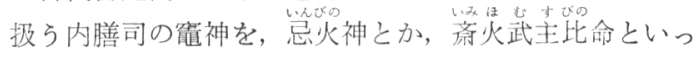
て斎祀したが、これはまぎれるなく忌火の神格化であっ た。宮中の筐神に関しては, 『続日本紀』(卷11) に,

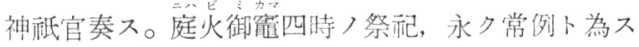
(天平三 (731) 年正月甘六日条)

とある。この記事は, この時点で神, 祙官が竅神に対し 四季の祭儀を正式汇執行する旨を公告したものであるか ら，この祭義はこれ以前からすでに行われていたことが 察知される。ところが, この庭火御瓮が, 宮中の内譜 司・大膳司・大炊寮などに祭妧された䇴神のうち, どれ に該当するのか明らかではない。しかし，『延喜式』(卷 32, 大㺊司) には,

御膳神八座, 高部神一座, 筐神四座, 售神四座

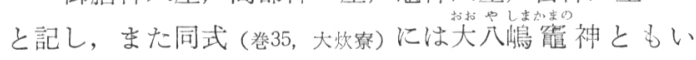
われた「籃神入座」を録している。いずれの場合も各神 々の祭神料を挙げ，なお春秋に祭荆する旨を明記してい る点に着目したい。

なお籃神について興味あることは『日本書紀』(巻27)に, 大炊省に八つの鼎有りて鳴る。或いは二つ, 或い は三つ镇に鳴る。或いは八つながら鳴る(天智天皇十 (617) 年条)

とあるように，古くからその神威が恐机られていた。と いうのは, これらの䆚が不気味な音を立てて鳴るところ から，神意を伺い，吉凶を表わすものと信じられていた。 このことは,『延喜式』(卷3, 神触・三) の「臨時祭」条に, 「鎮二筐鳴一祭」とある記事からも推測できる。

内膳司の䇥神は忌火神とか, 庭火皇神といわれた。同 式 (卷16, 㓌晹寮) 飞「庭火并平野穽神祭」と録されている ので, 忌火神・庭火皇神を加光て平野熋神の神祭りが行 われ，その祭日は毎揆日の吉日が選ばれた。また同式 (巻 2, 神祚・二) の「四時祭下」条に,

毎月䍭日忌火庭火祭中宮東宫庭火猚々此, 但忌火不々 祭 と見克、いずれも祭神料を挙げている。さらに同式(卷 3, 神旅・三) の「臨時祭」条には, 「御竉祭」, 「御井并御 筐”祭」, さらに「中宮御熋祭東宮レ准之」などの条目が挙 け゚られている。

次汇平野熋神は, 平安遷都の前年, 793 (趜暦 12) 年に 大和国から遷座した平野社の祭神「釜」のことである。 な打同社の祭神については, 同式 (卷1, 神践・一) の「四 時祭上」の条に,

平野神四座祭今棉・ 久度神・古開神・相殿比壳神 とある。このうち, 「久度神」はまぎれもなく䇫神であ

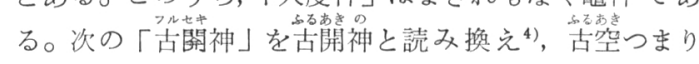


用済みになった簿の意に解しているが，これは余りにも 染意的ではなからうか。「閶」はハンとかヒンと読み, 柱 の栟型とか, 柱上の方木の意で,「開」とは明らかに異義 である。したがって古開神を古開神と読む通説は受け入 れがたい。また, 内膳司の「平野御䆰神二口」とは, 打 そらく久度神と古閵神のことであろう。いずれにしても， 蕃神的色彩の濃い平野社は, 百済王の価と伝兄られる帰 化氏族, 和氏の奉斎神で, しかも大陸渡来の䆛神が祭祀 されていることに強く興味がそそられる。この点次報5 で記述する。

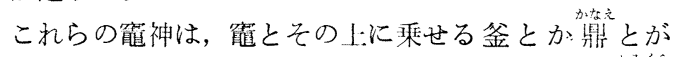
セットになって扣り，簏神は篐そのものよりも釜を神座

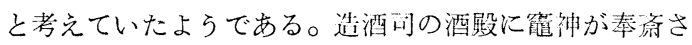
れていたことは，酒造り作業において不可火の道具であ っただけにむしろ当然のことであった。

これまでの神話的，あるいは民間信仰的考察にもかか わらず, 造酒司酒殿に祭祀された「箍神四座」とは, どのような神々に比定されるのか，具体的に明確化する

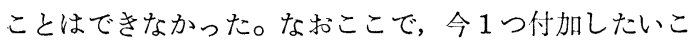
とは, 造酒司の「祭神九座」のらち, これら「四座 筐 神」だけは神階の記載がないことである。では，篐神の ぞれもが神階がなかったかといえば, 内膳司の䆝神は叙 位されている。では，なぜ造酒司の霆神だけが叙位され なかったのであろらか, その点に別の興味が引かれるも のの, その理由については明らかではない。

\subsection{3 大邑刀自・小邑刀自・次邑刀自}

『延喜式』(巻40, 造酒司) によれば，宮中造酒司に祭祀さ れていたのは「祭神九座」であったはずである。ところ が『特撰神名牒』を見ると，

造酒司坚神六座大四夾・小二坐

とありまた江戸後期，伴信友の『神名帳考証』にも，

造酒司坐神六座大四座・小二座（宮中）

とある。したがって, 両書の記事は『古今要覽稿』に,

造酒司にまします神六座のうち四座は大なり二座は 小なり

とある記事の傍証にはなっても，なぜ造酒司の「祭神九 座」が「造酒司坐神六座」に減少してしまったのか，そ の理由については何も説明されていない。ところで『延 喜式』(巻 9, 神名・上)には,

造酒司坐神六座 大四夾・小二夾

と見光，その内訳として，

大宮売神社 四座 並大・並・新當

酒殿神社 二夾酒弥豆男神・济弥豆女神

と記している。したがって『特撰神名牒』『神名帳考証』 『古今要覧稿』などの記事は，いずれる『延喜式』(卷9，神名・ 上）引用していることが確認される。
では,なぜ同式 (炎40) の「造酒司」の条には「祭神九 座」とあるのに, 同式 (卷9) の「神名・上」条に, 「造 酒司坐神六座」と録されているのであるらか。その理由 として, 次の神々,

三座还五位下大员刀自・従五位下小量刀自・次邑刀自 を外したといえばことは簡単であるが，果してそれだけ のことで放ろらか。たとえばこれら 3 座の神々は, 造酒 司上り別の所の方がいっそう神德を発揮されるであろう とか, あるいは他からのたっての要望で遷座を願ったと かなどの理由が考えられる。しかし，外に傍証資料が見 出せないので, これ以上勝手な推理は許されない。

たまたまこ礼ら 3 座の神々の動向について,『古今要 稿』は,

宮内省にまします神三柱はともに素战鳴尊の御子 なれば，大となさるべきことむべなり

と記している。もし，この記事をそのまま率直に受け入 れるとすれば，次の 2 つの知見が得られる。

1）『延喜式』(巻 40 , 造酒司) 飞記載された「祭神九座」 のうち, 造酒司酒殿から外された 3 座の神々は, 宮内省 に奉祀されていることが明白になった。しかし，どんな 理由で，いっ遷座されたのかは全く分からない。

2）これら 3 座の神々については『神名帳考証』に,

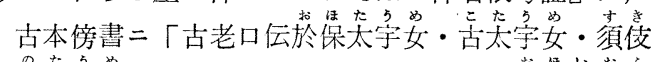
乃太宁茹卜云, 字二就テ之ヨ案ズル二, 於保伊於希

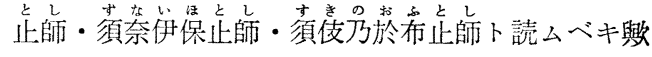
といったごく簡単な考証が見られるものの, これから直 ちにこれらの神々の出自を引き出すことはできないし， また，この古老の口伝の意味もよく理解できない。

そこで, 『古今要覽稿』に「神三柱はともに素戔鳴尊 の御子」とあったので, 早速『記・紀』神話を調べるこ とにした。まず『古事記』(神代記)から, 尊の御子とい

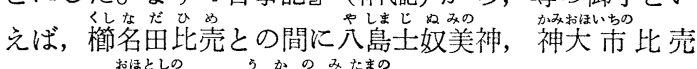
との間に大㔖哖神と宇迦之御魂神の, 3 柱の神があった ことが知られる。次に『日本書紀』(神代記・第8段) の「一 書第1」からは, 稻田媛との間に清湯山主三名狭漏彦六 嶋涤だけであるが，同段「一書第5」には，五十猛命 大桨屋㴖姫命・柧津姫命の「神三柱」の名が見える。それ では『延喜式』の「三座の神」とは，『記』(神代記) の 3 柱の神を指すのか，それとも『紀』(神代紀・第 8 段・一書第 5)の「神三柱」に該当するのか, 確証のない限り簡単 には決められない。したがって、「神三柱」についての 考証はこれ以上展開できない。つまり大邑刀自・小邑刀 自・次邑刀自の 3 座の神々の出自もまた明確化すること はできなかった。

ところで，大邑刀自・小邑刀自・次邑刀自の 3 神は， 『三代実録』(巻 13 ，貞観入 (866) 年十一月一日条) に, 
造酒司従五位下次邑刀自畄神八大邑刀自 - 小邑刀自

鸐神等二准テ, 春秋二季祭二預ル

とあるので，鶽神，つまり酒巂の神であることは間違い ない。なお踥古事談』には，

造酒司ノ大刀自卜云ツボ八三十石入也 などとあるので，その容量も推定されるであろう。

これまで，宮中造酒司でく旨酒>が出来るように，酒 人らが祈念した「造酒司酒殿坐神九座」について, 各神 々の出自己神徳を考察したところ，次の知見をえた。

1）「二座 酒弥豆男神・酒弥豆女神」は，酒造用水 を守護する男女 2 神であることが分かったものの，各神 の出自については不詳である。

2）「四座 涟神」は，筐そのものより鉒を神座とし
た忌火神で，大陸渡来の蕃神であることが分かった。

3）「三座 大邑刀自・小邑刀自・次邑刀自」は酒鶽 の神であるが，その出自も神徳も不詳である。

4）古代の酒造りで何が重要視されていたか知るら兄

で「祭神九座」は極めて興味ある存在である。

\section{参考 文 献}

1）平野邦雄 : 「㷌化人の役割」・古代の日本 (1) 要説』p. 124〜144 角川書店 (昭 46)

2) 式内社研究会編：『式内社調查報告 (1) 宮中・京中・山城国』p. 32 皇学館大学出版 (昭 54)

3) 松前 健:『古代伝承と宮廷祭祀』 p. 355 367 塙書房（昭 49）

4) 全国神社名鑑刊行会・史学センター編：『全国神社名鑑，下巻』 p. 89 , 同会（昭 52）

5) 加藤百一：「酒神と神社（11）」酸協・投稿中 